\title{
The effect of ocean acidification on tropical coral calcification: insights from calcification fluid DIC chemistry
}

Nicola Allison ${ }^{*}$, Catherine. Cole ${ }^{\mathrm{a}}$, Chris Hintz $^{\mathrm{b}}$, Ken Hintz ${ }^{\mathrm{c}}$, James Rae ${ }^{\mathrm{a}}$, Adrian Finch ${ }^{\mathrm{a}}$

*Corresponding author, email: na9@st-andrews.ac.uk

${ }^{a}$ School of Earth and Environmental Sciences, University of St. Andrews, St. Andrews KY16 9AL, UK

${ }^{b}$ Department of Marine and Environmental Sciences, Savannah State University, Savannah, GA USA

${ }^{c}$ Department of Electrical and Computer Engineering, George Mason University, Fairfax, VA, USA

\begin{abstract}
Ocean acidification typically reduces calcification in tropical marine corals but the mechanism for this process is not understood. We use skeletal boron geochemistry $\left(\mathrm{B} / \mathrm{Ca}\right.$ and $\left.\delta^{11} \mathrm{~B}\right)$ to reconstruct the calcification fluid DIC of corals cultured over both high and low seawater $\mathrm{pCO}_{2}(180,400$ and $750 \mu \mathrm{atm})$. We observe strong positive correlations between calcification fluid $\mathrm{pH}$ and concentrations of the DIC species potentially implicated in aragonite precipitation (be they $\mathrm{CO}_{3}{ }^{2-}$, $\mathrm{HCO}_{3}{ }^{-}$or $\mathrm{HCO}_{3}{ }^{-}+\mathrm{CO}_{3}{ }^{2-}$ ). Similarly, with the exception of one outlier, the fluid concentrations of precipitating DIC species are strongly positively correlated with coral calcification rate. Corals cultured at high seawater $\mathrm{pCO}_{2}$ usually have low calcification fluid $\mathrm{pH}$ and low concentrations of precipitating DIC, suggesting that a reduction in DIC substrate at the calcification site is responsible for decreased calcification. The outlier coral maintained high $\mathrm{pH}_{\mathrm{CF}}$ and $\mathrm{DIC}_{\mathrm{CF}}$ at high seawater $\mathrm{pCO}_{2}$ but exhibited a reduced calcification rate indicating that the coral has a limited energy budget to support proton extrusion from the calcification fluid and meet other calcification demands. We find no evidence that increasing seawater $\mathrm{pCO}_{2}$ enhances diffusion of $\mathrm{CO}_{2}$ into the calcification site. Instead the overlying $\left[\mathrm{CO}_{2}\right]$ available to diffuse into the calcification site appears broadly comparable between seawater $\mathrm{pCO}_{2}$ treatments, implying that metabolic activity (respiration and photosynthesis) generates a similar $\left[\mathrm{CO}_{2}\right]$ in the vicinity of the calcification site regardless of seawater $\mathrm{pCO}_{2}$.
\end{abstract}

Keywords: $\mathrm{B} / \mathrm{Ca}$, dissolved inorganic carbon, coral, calcification, $\delta^{11} \mathrm{~B}$, calcification fluid

Declarations of interest: none

\section{Introduction}

Rising atmospheric $\mathrm{CO}_{2}$ has fundamentally affected seawater carbonate chemistry, lowering seawater pH (Caldeira and Wickett, 2003; IPCC, 2013). Understanding the impact of these changes on coral biomineralisation is essential for predicting the future of coral reef ecosystems. Most laboratory and field studies indicate that coral calcification is reduced at lower seawater $\mathrm{pH}$ 
(Erez et al., 2011), but it is unclear why this occurs. Multiple studies explore correlations between calcification rate and seawater dissolved inorganic carbon (DIC) chemistry e.g. $\left[\mathrm{CO}_{3}{ }^{2-}\right],\left[\mathrm{HCO}_{3}{ }^{-}\right], \mathrm{pH}$ and $\Omega$ (Marubini et al., 2001; Schneider and Erez 2006; Jury et al., 2009). However, coral aragonite does not precipitate directly from seawater but from an extracellular calcifying fluid which multiple techniques (microsensors, $\mathrm{pH}$ sensitive dyes and skeletal boron geochemistry) indicate has significantly different DIC chemistry to the surrounding seawater (AI Horani et al., 2003; Venn 2011; Allison et al., 2014, Cai et al., 2016). The calcification fluid is probably derived from seawater (Tambutte et al., 2012) and located between the coral tissue and underlying skeleton (Clode and Marshall, 2002). Corals actively increase the $\mathrm{pH}$ of the fluid above that of seawater (Al Horani et al., 2003; Venn et al., 2011, 2012; Cai et al., 2016). This may serve as a mechanism to concentrate DIC, one of the substrates required for aragonite precipitation (Allison et al., 2014). Increasing calcification fluid $\mathrm{pH}$ shifts the $\mathrm{DIC}$ equilibrium in favour of carbonate $\left(\mathrm{CO}_{3}{ }^{2-}\right)$ at the expense of $\mathrm{CO}_{2}$ and bicarbonate $\left(\mathrm{HCO}_{3}{ }^{-}\right)$, creating a $\mathrm{CO}_{2}$ concentration gradient between the fluid and the surrounding environment. $\mathrm{CO}_{2}$ can diffuse into the calcification fluid and react to form more $\mathrm{HCO}_{3}{ }^{-}$and $\mathrm{CO}_{3}{ }^{2-}$, thereby increasing calcification fluid DIC (Erez 1978). Corals cultured at high seawater $p \mathrm{CO}_{2}$ have lower calcification fluid $\mathrm{pH}$ than their counterparts cultured at low $\mathrm{pCO}_{2}(\mathrm{Venn}$ et al., 2012; McCulloch et al., 2012). This suggests that they are unable to concentrate DIC at the calcification site to the same extent and may explain the reduction in calcification rate.

The DIC chemistry of the coral calcification fluid can be estimated from the boron geochemistry of the coral skeleton (Allison et al., 2014, McCulloch et al., 2017, Ross et al., 2017). In brief, there is a large $\mathrm{B}$ isotope fractionation between the predominate dissolved boron species in seawater and borate, $\mathrm{B}(\mathrm{OH})_{4}$, is depleted in ${ }^{11} \mathrm{~B}$ compared to boric acid, $\mathrm{B}(\mathrm{OH})_{3}$ (Kakihana et al., 1977). B speciation is controlled by ambient $\mathrm{pH}$ and the $\delta^{11} \mathrm{~B}$ of $\mathrm{B}(\mathrm{OH})_{4}^{-}$is therefore $\mathrm{pH}$ dependent. Since $\mathrm{B}(\mathrm{OH})_{4}^{-}$is predominantly incorporated into the aragonite lattice (Sen et al., 1994, Noireaux et al., 2015, Balan et al., 2016), skeletal $\delta^{11} \mathrm{~B}$ reflects calcification fluid $\mathrm{pH}$ while [B] reflects both fluid $\mathrm{pH}$ and the concentration of the DIC species competing with borate for inclusion in the carbonate (Allen et al., 2012).

In this study we have analysed the boron geochemistry of a suite of corals cultured over a range of seawater $\mathrm{pCO}_{2}$, including concentrations both lower and higher than the present day. The application of coral boron geochemistry assumes that aragonitic boron predominately occurs in tetrahedral coordination (B4), likely as $\mathrm{B}(\mathrm{OH})_{4}{ }^{-}$substituted for $\mathrm{CO}_{3}{ }^{2-}$ (Balan et al., 2016). However Klochko et al. (2009) reported $36 \%$ of boron in trigonal co-ordination (B3) in the shallow tropical coral Porites spp. while Rollion Bard et al. (2011) identified 18\% and $48 \%$ B3 in the skeletal fibres and centres of calcification respectively of a deep water coral. Klochko et al (2009) and Noireaux et al (2015) report good agreement between the observed aragonite $\delta^{11} \mathrm{~B}$ and that predicted from the incorporation of $\mathrm{B}(\mathrm{OH})_{4}^{-}$, leading both to conclude that any $\mathrm{B} 3$ was initially incorporated as $\mathrm{B} 4$ and then underwent a coordination change whilst preserving the original $\mathrm{B}(\mathrm{OH})_{4}^{-}$isotopic signature. In contrast, in the deep sea coral, high $B 3$ was associated with low $\delta^{11} B$ suggesting that $B(O H)_{3}$ was incorporated in the skeletal centres of calcification (Rollion Bard et al., 2011). During this research we avoided the analysis of centres of calcification and we assume that coral skeletal boron is derived from dissolved $\mathrm{B}(\mathrm{OH})_{4}$. We cultured three different massive Porites spp. genotypes, cutting multiple colonies (each $>12 \mathrm{~cm}$ in diameter) from coral heads to enable the study of large individuals of the same genotype over a range of seawater $\mathrm{pCO}_{2}$. We reconstruct the DIC chemistry of the coral calcification fluids and correlate this with measured coral calcification rates 
(Cole et al., 2018).

\section{Methods and materials}

\subsection{Coral culturing}

Large coral heads were collected from spatially separate (non-adjoining) massive Porites spp. colonies in Fiji and imported into the UK. We defined each massive colony as a separate genotype and divided each head into multiple pieces (each $\sim 12 \mathrm{~cm}$ in diameter) to enable the culture of corals of the same genotype in each $\mathrm{pCO}_{2}$ treatment. Corals were cultured in a purpose-built largevolume aquarium system constructed of low $\mathrm{CO}_{2}$ permeability materials and designed to control temperature, salinity and dissolved inorganic carbon (DIC) system parameters within narrow limits (Cole et al., 2016, 2018). The corals were maintained in 21 I cast acrylic tanks, recirculated with seawater from high density polyethylene reservoirs containing $~ 900$ litres of seawater. At the start of the experiment the reservoirs were filled with fresh artificial seawater (Red Sea Salt, Red Sea Aquatics, UK) seeded with artificial seawater from a mixed coral/fish aquarium. During tank cleaning, $\sim 10-15$ I of seawater was typically removed from each reservoir each week and was replaced with fresh artificial seawater. No seawater replacement occurred during the experimental period (see below).

The seawater in each treatment was bubbled with gas mixes set to reach the target seawater $\mathrm{pCO}_{2}$ compositions. Corals were cultured at seawater $\mathrm{pCO}_{2}$ of $\sim 180 \mu$ atm (the $\mathrm{CO}_{2}$ atmosphere during the last glacial maximum, Petit et al., 1999), $400 \mu$ atm (the present day) and $750 \mu$ atm (projected to occur by the end of the present century, IPCC 2013). Physical and chemical parameters of the culture seawater are summarised in Table 1. Seawater temperatures were measured hourly (TinyTag Aquatic, Gemini Data Loggers, UK) salinities were measured twice daily on 4 days of each week in the experimental periods (Thermo Orion 5 star meter, calibrated to NIST conductivity standards). Total alkalinity was measured by automated Gran titration (Metrohm, 888 Titrando) twice daily on 4 days of each week in the experimental periods. Precision of duplicate $\sim 30 \mathrm{ml}$ analyses was typically $\pm 2 \mu \mathrm{eq} \mathrm{kg}^{-1}$. The precision of multiple measurements of synthetic $\mathrm{Na}_{2} \mathrm{CO}_{3}$ standards was consistently $\pm 3 \mu \mathrm{eq} \mathrm{kg}{ }^{-1}(1 \sigma$, between days). The total alkalinity, [Ca] and [Sr] of the culture seawater was maintained by additions of $0.6 \mathrm{M} \mathrm{Na}_{2} \mathrm{CO}_{3}$ and a mixture of $0.58 \mathrm{M}$ $\mathrm{CaCl}_{2}+0.02 \mathrm{M} \mathrm{SrCl}_{2}$ by $200 \mu$ l volume solenoid diaphragm pumps, evenly spaced over a 24 hour period, controlled by a custom-written MATLAB ${ }^{\circledR}$ dosing control program. DIC was measured weekly in each reservoir using a $\mathrm{CO}_{2}$ differential, non-dispersive, infrared gas analyser (Apollo SciTech; AS-C3). Samples were calibrated against a natural seawater certified reference material (CRM; A. Dickson, Scripps Institution of Oceanography). Internal reproducibility was calculated from the standard deviation of 8 replicate measurements of a single sample $(\sigma / \sqrt{ } n)$, and was always $\leq 0.1 \%$. Multiple measurements of the CRM analysed as an unknown were in excellent agreement with the certified value (within $5 \mu \mathrm{mol} \mathrm{kg}{ }^{-1}$, Cole et al., 2016). Lighting of $\sim 300 \mu \mathrm{mol}$ photons $\mathrm{m}^{-2} \mathrm{~s}^{-1}$ was provided by Maxspect R420R 160w-10000k LED lamps on a $12 \mathrm{~h}$ light: $12 \mathrm{~h}$ dark cycle (with wavelength settings of $100 \%$ A and $20 \%$ B). Corals were fed weekly with frozen rotifers.

Corals were maintained at ambient $\mathrm{pCO}_{2}$ conditions for 2 months, adjusted to $\mathrm{pCO}_{2}$ treatment conditions over another 2 months and then acclimated at the final treatment $\mathrm{pCO}_{2}$ for 5 months. Colonies were then stained with Alizarin Red $S$ and cultured for a 5 week experimental period 
before sacrifice. Light and dark colony calcification rates were estimated 3-4 times in this experimental period by isolating the colony for 5 (in the light) or 7 (in the dark) hours and using the alkalinity anomaly technique (Cole et al., 2018).

\subsection{Seawater $\mathrm{B} / \mathrm{Ca}$ and $\delta^{11} \mathrm{~B}$ analyses}

Seawater samples were collected weekly during the experimental period and analysed for $\mathrm{B}$ and Ca by quadrupole ICP-MS (Thermo Scientific X Series) at the National Oceanography Centre, Southampton. Samples were diluted 1000 -fold in $5 \% \mathrm{HNO}_{3}$ (with $5 \mathrm{ppb}$ In as an internal standard) and calibrated against matrix-matched synthetic standards prepared from $1000 \mu \mathrm{g} \mathrm{ml}^{-1}$ singleelement stock solutions (Inorganic Ventures) in $5 \% \mathrm{HNO}_{3}$. Replicate analyses $(\mathrm{n}=4)$ of a standard seawater yielded a $\mathrm{B} / \mathrm{Ca}$ standard deviation of $1.5 \%$. Boron isotopes were separated from the seawater matrix by column chromatography and analysed on a Neptune Plus MC-ICPMS (Rae et al., 2011). The long-term reproducibility of these measurements is $0.2 \%$ (2 SD).

\subsection{Skeletal $\delta^{11} B$ and $B / C a$ analyses}

Corals were immersed in 3-4\% sodium hypochlorite for $\geq 24 \mathrm{~h}$ with intermittent agitation to remove organic contamination, then rinsed repeatedly in distilled water and dried. Skeletal strips from the outermost surface of the colonies were sawn along the maximum growth axes and fixed in $25 \mathrm{~mm}$ epoxy resin blocks (Epofix, Struers Ltd.). Blocks were polished using silicon carbide papers (up to 4000 grade, lubricated with water) and polishing alumina $(0.05 \mu \mathrm{m}$, suspended in water).

Skeletal $\delta^{11} \mathrm{~B}$ and $\mathrm{B} / \mathrm{Ca}$ were determined by SIMS using a Cameca 1270 in the School of GeoSciences at the University of Edinburgh. The experimental period was identified from the Alizarin Red S stain and multiple SIMS analyses $(n=17-24)$ were evenly spaced across this section of the skeleton in 2-5 different corallites of each colony. The high spatial resolution of SIMS allows the selective analysis of the small volumes of aragonite deposited in the experimental period and the avoidance of centres of calcification which appear as dark areas in reflected light when exposed on the section surface (Allison and Finch 2009). Sections were gold coated and analysed with a primary ${ }^{16} \mathrm{O}_{2}-$ beam of $\sim 7 \mathrm{nA}$, accelerated at $22 \mathrm{keV}$ and focussed to an oval $\sim 25 \times 35 \mu \mathrm{m}$. Instrument conditions were energy offset $=0 \mathrm{eV}$ (100 eV window), imaged field $=25 \mu \mathrm{m}$, entrance slits $150 \mu \mathrm{m}$ and exit slits $500 \mu \mathrm{m}$ (mass resolution was $\sim 2400$ ). Secondary ions were collected by a single electron multiplier and by cycling the magnetic field through the mass range. Singlycharged cations were collected at masses ${ }^{10} \mathrm{~B}$ (11 seconds per cycle) and ${ }^{11} \mathrm{~B}(3 \mathrm{~s})$ yielding typical count rates of $\sim 1400$ and $5300 \mathrm{cps}$ respectively. Doubly charged ${ }^{40} \mathrm{Ca}^{2+}$ ions were collected at mass 20 (1s) and typical count rates were $\sim 60000 \mathrm{cps}$. Each analysis is the sum of 60 cycles. A pre-analysis sputter time of $30 \mathrm{~s}$ in spot mode was used to remove surface contamination. Internal reproducibility (the precision at a single point) was calculated from the standard deviation $(\sigma)$ of the 60 cycles in each coral analysis $(\sigma /(\sqrt{60}))$ and was typically $1.6 \%$. The precision $(1 \sigma)$ of multiple analyses of each coral sample was typically $1.4 \%\left(\delta^{11} \mathrm{~B}\right)$ and $9 \%(\mathrm{~B} / \mathrm{Ca})$.

All analyses were normalized to a Porites spp. coral standard $\left(\delta^{11} \mathrm{~B}=24.8 \%\right.$ o, $\mathrm{B} / \mathrm{Ca}=$ $0.364 \mathrm{mmol} \mathrm{mol}^{-1}$, Kasemann et al., 2009). Minor differences in the $\mathrm{B} / \mathrm{Ca}$ and $\delta^{11} \mathrm{~B}$ of the SIMS coral standard and the chips of the same coral characterised by bulk methods may affect the accuracy of our SIMS estimates but our estimates of analytical precision are good. A 
Desmophyllum spp. cold water coral chip $\left(\delta^{11} \mathrm{~B} \approx 16.7 \pm 1.2 \%\right.$ o $(1 \sigma) ; \mathrm{B} / \mathrm{Ca} \approx 0.15 \mathrm{mmol} \mathrm{mol}^{-1} \pm 3 \%$ $(1 \sigma)$, based on comparison with the coral standard) which exhibited limited heterogeneity in $\mathrm{B} / \mathrm{Ca}$ and $\delta^{11} \mathrm{~B}$ was analysed to confirm that there was no instrumental drift within and between days. Multiple analyses were completed each day $(n=9-13)$ to yield a $95 \%$ confidence limit of the mean $\delta^{11} \mathrm{~B}$ of the standard which was typically $\sim 0.9 \%$ and was always better than $\pm 1.2 \%$. $95 \%$ confidence limits of the mean $\mathrm{B} / \mathrm{Ca}$ of the standard was always $\leq \pm 2.6 \%$.

\subsection{Calculation of calcification fluid DIC parameters}

Equilibrium constants and their $\mathrm{p} K$ values were calculated from the known temperatures and salinity of the culture seawater in each treatment (Table 1.). Equilibrium constants for carbonic acid were calculated from Mehrbach et al. (1973), refit by Dickson and Millero (1987) and for $\mathrm{KHSO}_{4}$ from Dickson (1990). $E_{\mathrm{CF}} \mathrm{pH}$ was estimated from skeletal $\delta^{11} \mathrm{~B}$ as:

$$
\mathrm{pH}_{\mathrm{ECF}}=p K_{\mathrm{B}}-\log \left(-\frac{\delta^{11} \mathrm{~B}_{\mathrm{ECF}}-\delta^{11} \mathrm{~B}_{\text {skeleton }}}{\delta^{11} \mathrm{~B}_{\mathrm{CF}}-\alpha_{\mathrm{B}} \delta^{11} \mathrm{~B}_{\text {skeleton }}-1000\left(\alpha_{\mathrm{B}}-1\right)}\right.
$$

using $\alpha_{\mathrm{B}}(=1.0266$, the mean of two empirical estimates (Klochko et al., 2006, Nir et al., 2015) and assuming that the $\delta^{11} \mathrm{~B}$ of the calcification fluid $\left(\delta^{11} \mathrm{~B}_{\mathrm{CF}}\right)$ is the same as culture seawater (Table 1).

Dissolved boron is transported into the calcification fluid in seawater and we infer that the total [B] of the fluid is the same as the seawater in each treatment (Table 1) and is constant (reflecting the very low partitioning of $\mathrm{B}(\mathrm{OH})_{4}{ }^{-}$into aragonite, Allison et al. 2014). We assume that $\left[\mathrm{B}(\mathrm{OH})_{4}{ }^{-}\right]$only partitions into aragonite and we used $\mathrm{pH} \mathrm{CF}_{\mathrm{CF}}$ to estimate $\left[\mathrm{B}(\mathrm{OH})_{4}\right]_{\mathrm{CF}}$ :

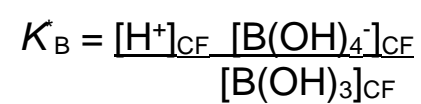

$\mathrm{B} / \mathrm{Ca}_{\text {skeleton }}$ equates to $\mathrm{B} / \mathrm{CO}_{3}{ }^{2-}$ skeleton as $\mathrm{Ca}$ and $\mathrm{C}$ are equimolar in $\mathrm{CaCO}_{3}$. We used $\left[\mathrm{B}(\mathrm{OH})_{4}{ }^{-}\right]_{\mathrm{CF}}$, $\mathrm{B} / \mathrm{Ca}_{\text {skeleton }}$ and the relevant $\mathrm{B}(\mathrm{OH})_{4}{ }^{-} /\left(\mathrm{co}\right.$-precipitating $\mathrm{DIC}$ species) partition coefficient $\left(\mathrm{K}_{\mathrm{D}}\right)$ to estimate the concentration of the DIC species co-precipitating with $\mathrm{B}(\mathrm{OH})_{4}{ }^{-}$in the calcification fluid e.g. if $\mathrm{B}(\mathrm{OH})_{4}{ }^{-}$co-precipitates with $\left[\mathrm{CO}_{3}^{2-}\right]$ then:

$$
\mathrm{B} / \mathrm{Ca}_{\text {skeleton }}=K_{D} \mathrm{~B}(\mathrm{OH})_{4}{ }^{-} / \mathrm{CO}_{3}{ }^{2-} \quad \mathrm{x} \quad \frac{\left[\mathrm{B}(\mathrm{OH})_{4} 4_{\mathrm{CF}}\right.}{\left[\mathrm{CO}_{3}{ }^{-2}\right]_{\mathrm{CF}}}
$$

$K_{D}$ have been calculated for aragonite under a range of different scenarios (Allison et al., 2014, 2017, Mavromatis et al., 2015, Holcomb et al. 2016 and De Carlo et al., 2018). While it is likely that $\mathrm{B}(\mathrm{OH})_{4}^{-}$substitute for $\mathrm{CO}_{3}{ }^{2-}$ in aragonite (Balan et al., 2016), it is unknown which aqueous DIC species are involved in aragonite precipitation. De Carlo et al (2018) conclude that insignificant correlations between fluid $\left[\mathrm{HCO}_{3}{ }^{-}\right]$and precipitation rates of inorganic aragonites indicate that $\mathrm{HCO}_{3}{ }^{-}$is not involved in precipitation. However they did not utilise a seed in their experiments and they are unable to discriminate between the rates of $\mathrm{CaCO}_{3}$ nucleation (likely controlled by $\mathrm{CO}_{3}{ }^{2-}$, Gebauer et al., 2008) and subsequent crystal growth. Both aqueous $\mathrm{HCO}_{3}{ }^{-}$and $\mathrm{CO}_{3}{ }^{2-}$ are inferred to attach to growing calcite crystal surfaces with the $\mathrm{HCO}_{3}{ }^{-}$subsequently deprotonating to leave $\mathrm{CO}_{3}{ }^{2-}$ preserved in the carbonate lattice (Wolthers et al., 2012). $\mathrm{HCO}_{3}{ }^{-}$is observed in both coral 
and synthetic aragonite which may be a remnant of attached un-deprotonated $\mathrm{HCO}_{3}{ }^{-}$(Von Euw et al., 2017).

Holcomb et al (2016) identified an effect of saturation state on $\mathrm{K}_{\mathrm{D}}$ in synthetic aragonites which complicates the interpretation of coral skeletal [B]. McCulloch et al., (2017) replotted the Holcomb et al. data to describe $K_{D}$ as a function of precipitating fluid $\left[\mathrm{H}^{+}\right]$reasoning that $\mathrm{B}(\mathrm{OH})_{4}^{-}$likely deprotonates during substitution for $\mathrm{CO}_{3}{ }^{2-}$ to preserve charge neutrality. However $\mathrm{B}(\mathrm{OH})_{4}^{-}$deprotonation is not supported by experimental NMR data (Balan et al., 2016) and charge neutrality during $\mathrm{B}(\mathrm{OH})_{4}^{-}$substitution for $\mathrm{CO}_{3}{ }^{2-}$, is likely accomplished by substitution of $\mathrm{Na}^{+}$for $\mathrm{Ca}^{2+}$ (Balan et al., 2016). Neither the De Carlo et al. (2018) or McCulloch et al., (2017) replots of the Holcomb dataset consider the large variations in $\left[\mathrm{Ca}^{2+}\right](\mathrm{x} 3)$ which occur in the Holcomb et al (2016) dataset and affect fluid saturation state.

Allison (2017) replotted the combined datasets of Mavromatis et al. (2015) and Holcomb et al (2016) for synthetic aragonites precipitated at $25^{\circ} \mathrm{C}$ to show that $K_{D}$ is highly dependent on precipitating fluid saturation state. This may reflect enhanced incorporation of $B$ during rapid crystal extension, as in calcite (Gabitov et al., 2014). However observed patterns in coral skeletal B/Ca can only be reproduced assuming that $K_{D}$ is approximately constant (Allison, 2017). This apparent conflict can be resolved if changes in the coral calcification fluid saturation state are not associated with increases in crystal extension rate e.g. if increases in coral calcifying fluid saturation state are associated with increases in the numbers of aragonite crystals deposited rather than the extension rates of individual crystals (Allison, 2017).

In this study we utilize the $\mathrm{B}(\mathrm{OH})_{4}$ /precipitating DIC aragonite partition coefficients calculated in Allison (2017) from the Holcomb et al (2016) dataset. We assume $\mathrm{B}(\mathrm{OH})_{4}$ - substitutes into aragonite for either $\mathrm{CO}_{3}{ }^{2-}$ only, $\mathrm{HCO}_{3}{ }^{-}$only or both $\mathrm{HCO}_{3}{ }^{-}+\mathrm{CO}_{3}{ }^{2-}$ and apply $\mathrm{B}(\mathrm{OH})_{4}-\mathrm{CO}_{3}{ }^{2-}$, $\mathrm{B}(\mathrm{OH})_{4}{ }^{-} / \mathrm{HCO}_{3}{ }^{-}$and $\mathrm{B}(\mathrm{OH})_{4}{ }^{-} /\left(\mathrm{CO}_{3}{ }^{2-}+\mathrm{HCO}_{3}{ }^{-}\right)$partition coefficients of $1.05 \times 10^{-3}, 6.36 \times 10^{-3}$ and $6.99 \times 10^{-3}$ respectively (Allison, 2017). We note that fluid saturations states within single aragonite precipitations in the Holcomb study are highly variable $\left(\left[\mathrm{Ca}^{2+}\right]\right.$ typically varies by up to $x 3$, while [DIC] varies by up to $x 4$ ) and we consider that the calculated partition coefficients should be treated as broad approximations only.

\section{Results}

Seawater and skeletal $\mathrm{B} / \mathrm{Ca}$ and $\delta^{11} \mathrm{~B}$ data are summarised in Table 1. In all treatments, seawater [B] is close to natural values but $\delta^{11} B$ is $\sim-1 \%$. Commercial sea salts are formed from the evaporation of seawater resulting in the removal of $B$ in the water vapour phase (Gast and Thompson, 1959). Boron is replenished by the addition of boric acid yielding the high seawater $\delta^{11} \mathrm{~B}$ observed here.

We report all $\mathrm{pH}$ on the total scale and use the subscript $\mathrm{CF}_{\text {to }}$ to denote the DIC characteristics of the calcification fluid. We calculate fluid DIC assuming that $\mathrm{B}(\mathrm{OH})_{4}{ }^{-}$co-precipitates with $\mathrm{HCO}_{3}{ }^{-}$and/or $\mathrm{CO}_{3}{ }^{2-}$ and we express concentrations as $\left[\mathrm{CO}_{3}{ }^{2-}\right]_{\mathrm{CF}}$ (assuming that $\mathrm{CO}_{3}{ }^{2-}$ only is utilized during aragonite precipitation), $\left[\mathrm{HCO}_{3}^{-}\right]_{\mathrm{CF}}$ (assuming that $\mathrm{HCO}_{3}{ }^{-}$only is utilized during aragonite precipitation) and $\left[\mathrm{HCO}_{3}{ }^{-}+\mathrm{CO}_{3}{ }^{2-}\right]_{\mathrm{CF}}$ (assuming that both $\mathrm{HCO}_{3}{ }^{-}+\mathrm{CO}_{3}{ }^{2-}$ are utilized). We use the term [co-precipitating $\mathrm{DIC}$ ] to discuss observations which apply to all of these precipitation scenarios. We cultured and analysed two duplicate colonies of the $P$. murrayensis genotype at 400 and 
750 ratm seawater $\mathrm{pCO}_{2}$ (Table 1). We observed significant variations in $\mathrm{pH}_{\mathrm{CF}}$ (2 tailed t test, $\mathrm{p}=0.05$ ) between both duplicates although in only one case (at $750 \mu \mathrm{atm}$ ) was this associated with a significant difference in [co-precipitating DIC] $]_{C F}$.

All corals increased $\mathrm{pH}_{\mathrm{CF}}$ (Fig. 1a) above that of seawater (Table 1). All corals cultured at $180 \mu$ atm exhibited significantly higher $\mathrm{pH}_{\mathrm{CF}}$ than their analogues at $400 \mu$ atm and $750 \mu$ atm but $\mathrm{pH}_{\mathrm{CF}}$ did not vary significantly between $400 \mu \mathrm{atm}$ and $750 \mu \mathrm{atm}$ in any coral genotype (Table 2). $\mathrm{pH}_{\mathrm{CF}}$ and [coprecipitating $\mathrm{DIC}]_{\mathrm{CF}}$ exhibit a broad positive correlation under all co-precipitation scenarios (Fig 1b, $\left.r^{2}=0.57, p=0.008\right)$. Replotting this figure to discriminate between coral species, produces stronger coefficients of determination (Figure 2) and indicates that [co-precipitating DIC] is more concentrated in $P$. murrayensis than in $P$. lutea for a comparable $\mathrm{pH}_{\mathrm{CF}}$, yielding $\left[\mathrm{CO}_{3}{ }^{2-}\right]_{\mathrm{CF}}$ and $\left[\mathrm{HCO}_{3}{ }^{-}+\mathrm{CO}_{3}{ }^{2-}\right]_{\mathrm{CF}}$ values which are typically higher by $\sim 70 \mu \mathrm{mol} \mathrm{kg}{ }^{-1}$ and $\sim 400 \mu \mathrm{mol} \mathrm{kg}{ }^{-1}$ respectively.

\section{Discussion}

\subsection{Calcification fluid DIC chemistry}

Regardless of the co-precipitating DIC species, $\mathrm{pH}$ CF and [co-precipitating DIC] $]_{\mathrm{CF}}$ are positively correlated in each coral species (Figure 2). The opposite trend has been observed between seasonal variations in $\mathrm{pH}_{\mathrm{CF}}$ and [DIC] $]_{\mathrm{CF}}$ in modern corals from Australia (McCulloch et al., 2017, Ross et al., 2017). Seasonal variations in ambient seawater $\mathrm{pH}$, temperature and light likely impact coral carbon metabolism (photosynthesis and respiration), enzyme activities (e.g, Ca-ATPase pumping out of the calcification fluid) and calcification (which decreases $\mathrm{pH}_{\mathrm{CF}}$ ). These confounding effects do not occur in the present study enabling us to isolate the impact of seawater $\mathrm{pCO}_{2}$ on calcification fluid chemistry.

Our data indicate that increases in $\mathrm{pH}_{\mathrm{CF}}$ act to concentrate co-precipitating DIC at the calcification site. Increasing $\mathrm{pH}_{\mathrm{CF}}$ drives the DIC equilibrium to reduce calcification fluid $\left[\mathrm{CO}_{2}\right]$ and probably creates a $\mathrm{CO}_{2}$ concentration gradient between the fluid and the surroundings i.e. coral tissues and local seawater, which are separated from the fluid by a permeable membrane. We note that corals of each species fall along a common line, describing $\mathrm{pH}_{\mathrm{CF}}$ and [co-precipitating $\left.\mathrm{DIC}\right]_{\mathrm{CF}}$, regardless of seawater $\mathrm{pCO}_{2}$ treatment. To emphasize the importance of this we illustrate the [co-precipitating $\mathrm{DIC}$ ] of a seawater based fluid as a function of $\mathrm{pH}$ under two different $\mathrm{CO}_{2}$ diffusion scenarios. In the first scenario we assume that the system is fully open and that $\mathrm{CO}_{2}$ diffuses readily from the surroundings into the fluid to maintain an equilibrium with local seawater. $\mathrm{CO}_{2}$ diffusing into the calcification site predominantly converts to $\mathrm{HCO}_{3}{ }^{-}$and $\mathrm{CO}_{3}{ }^{2-}$ and all [co-precipitating $\mathrm{DIC}$ ] $\mathrm{CF}$ are positively correlated with $\mathrm{pH}_{\mathrm{CF}}$ (Fig $3 \mathrm{a}-\mathrm{C}$ ). In the second scenario we assume that $\mathrm{CO}_{2}$ diffuses into the system as in the open system but that the rate of diffusion is a function of the $\mathrm{CO}_{2}$ concentration gradient $\left(\Delta \mathrm{C}_{\mathrm{w}}\right)$ between the fluid and the seawater (see Allison, 2017 for full details and a sample calculation). We estimate the concentration gradient by assuming that the $\left[\mathrm{CO}_{2}\right]$ of the calcification fluid reflects that of ambient seawater brought to $\mathrm{pH}_{\mathrm{CF}}$ and that seawater $\left[\mathrm{CO}_{2}\right]$ is the same as ambient seawater in each $\mathrm{pCO}_{2}$ treatment (Fig. 4). We arbitrarily assume that $\mathrm{CO}_{2}$ diffusion doubles the [DIC] $]_{\mathrm{CF}}$ at pH 8.5 in the $400 \mu \mathrm{atm} \mathrm{CO}_{2}$ scenario (as in Allison 2017) and scale the addition of DIC to the calcification fluid over the full fluid $\mathrm{pH}$ in all $\mathrm{pCO}_{2}$ treatments as a linear function of this $\Delta \mathrm{C}_{\mathrm{w}}$ (Fig 3d-f). Although $\mathrm{CO}_{2}$ invasion is more limited in this second set of calculations (Allison 2017), both scenarios predict large variations in [co-precipitating DIC] $\mathrm{CF}$ 
between different seawater $\mathrm{pCO}_{2}$ treatments.

These predictions are in marked contrast with our observed data (overlain onto Fig 3). The coral data implies that the concentration of co-precipitating DIC in the calcification fluid is not affected by changes in seawater $\mathrm{pCO}_{2}$ between treatments i.e. increasing seawater $\mathrm{pCO}_{2}$ does not impact the $\mathrm{CO}_{2}$ available to diffuse into the calcification site (Hohn and Merico, 2012). Rather our data suggests that the overlying $\left[\mathrm{CO}_{2}\right]$ available to diffuse into the calcification site is broadly comparable between treatments implying that metabolic activities (respiration and photosynthesis) generates a similar $\left[\mathrm{CO}_{2}\right]$ in the vicinity of the calcification site regardless of seawater $\mathrm{pCO}_{2}$.

[Co-precipitating DIC] $]_{\mathrm{CF}}$ is higher in $P$. murrayensis than in $P$. lutea for a comparable $\mathrm{pH}_{\mathrm{CF}}$ (Fig. 2) Trace element partitioning into carbonates may be affected by mineral precipitation rate due to Rayleigh fractionation (Elderfield et al., 1996) or growth entrapment (Watson, 1994) but calcification rates for the 2 coral species are broadly comparable (Cole et al., 2018) and it is unlikely that this accounts for the offset in [DIC $]_{\mathrm{CF}}$. The more effective concentration of DIC in $P$. murrayensis could reflect a greater activity of bicarbonate anion transporters (Tambutte et al., 1996; Zoccola et al., 2015) in this species or a higher tissue $\left[\mathrm{CO}_{2}\right]$ which enables a greater diffusion of $\mathrm{CO}_{2}$ into the calcification site (Erez 1978).

$\mathrm{pH}_{\mathrm{CF}}$ varied significantly between duplicate colonies of the $P$. murrayensis at $400 \mu$ atm and 750 uatm. Water in the tanks was well mixed and duplicate differences do not reflect temperature, seawater $\mathrm{pCO}_{2}$ or nutrient levels. Similarly light variations over the tank footprint were small and photosynthetically active radiation light varied by 250-300 $\mu \mathrm{mol}$ photons $\mathrm{m}^{-2} \mathrm{~s}^{-1}$. The $\delta^{11} \mathrm{~B}$ of massive corals has been applied as a proxy of past and modern seawater $\mathrm{pH}$ and to indicate air:sea carbon flux (Pelejero et al., 2005; Shinjo et al., 2013; Kubota et al., 2014). The high pH CF variability observed between corals cultured at the same seawater $\mathrm{pCO}_{2}$ (even for prolonged periods of $>9$ months) suggests that it will be difficult to estimate past seawater $\mathrm{pH}$ accurately from fossil coral $\delta^{11} \mathrm{~B}$.

\subsection{Calcification fluid DIC chemistry and calcification rate}

We plotted calcification rate (from Cole et al 2018) against $\left[\mathrm{CO}_{3}{ }^{2}\right]_{\mathrm{CF}}$ and $\left[\mathrm{HCO}_{3}{ }^{-}+\mathrm{CO}_{3}{ }^{2-}\right]_{\mathrm{CF}}$ for each coral genotype (Fig. 5a). Assuming that calcification fluid $\left[\mathrm{Ca}^{2+}\right]$ is similar to that of seawater (Al Horani et al., 2003), this is effectively a measure of the saturation state of the calcification fluid. We observe excellent correlations between $\left[\mathrm{CO}_{3}{ }^{2-}\right]_{\mathrm{CF}}$ and $\left[\mathrm{HCO}_{3}{ }^{-}+\mathrm{CO}_{3}{ }^{2-}\right]_{\mathrm{CF}}$ and calcification rate in both $P$. lutea genotypes although we found the two genotypes exhibit markedly different relationships. $P$. lutea 1 attains higher calcification rates than $P$. lutea 2 , at comparable values of $\left[\mathrm{CO}_{3}{ }^{2}\right]_{\mathrm{CF}}$ or $\left[\mathrm{HCO}_{3}{ }^{-}+\mathrm{CO}_{3}{ }^{2-}\right]_{\mathrm{CF}}$, particularly at the lower ends of the $\mathrm{DIC}_{\mathrm{CF}}$ ranges. Clearly calcification rate variations between genotypes do not solely reflect calcification fluid DIC chemistry. Coral skeletons include soluble and insoluble organic materials which are present at the calcification site and/or are subsequently embedded in the skeleton (Clode and Marshall, 2002; Falini et al., 2013). These organic materials are implicated in the catalysis of crystallization and mediation of the skeletal architecture. For example, individual proteins, isolated from coral skeletal materials, can spontaneously catalyse the precipitation of aragonite at $\mathrm{pH}$ similar to that of seawater (Mass et al., 2013). The skeletal organic matrix amino acid composition varies between coral species (Van de Locht, 2014) and between corals of different growth rates (Falini et al., 2013). We hypothesise that the two $P$. lutea genotypes produce different skeletal organic materials which impact the 
precipitation rates of their respective skeletons.

The third coral genotype, $P$. murrayensis, also exhibits an excellent relationship between [coprecipitating $\mathrm{DIC}]_{\mathrm{CF}}$ and calcification rate with the exception of one point (Fig. 5a). Calcification rates for this outlier were highly variable (note the large standard deviation of this mean). Skeletal chemistry predominantly reflects the higher rate of variable calcification (in this case $14.1 \mathrm{mmol} \mathrm{CaCO}_{3} \mathrm{~cm}^{-2}$ day $^{-1}$ ), when most of the analysed skeleton was deposited, but even after accounting for this, the calcification rate of this outlier coral is lower than that expected from the [co-precipitating $\mathrm{DIC}]_{\mathrm{CF}}$ versus calcification rate relationship observed in the other colonies of this genotype. Plotting calcification rate as a function of the $\mathrm{H}^{+}$concentration gradient between the calcification fluid and the surrounding seawater produces strong inverse correlations in each genotype which span all coral samples with no outliers (Fig. 5b). Coral calcification is likely to be energetically expensive (Allemand et al., 2011) requiring synthesis of the skeletal organic matrix to guide precipitation of the skeleton and ion transport e.g. $\mathrm{H}^{+}$extrusion from the calcification site by Ca-ATPase (Al Horani et al., 2003). We hypothesise that the outlier coral in Fig. 5a may expend a large proportion of its energy budget in maintaining a relatively high $\mathrm{pH}_{\mathrm{CF}}$ at the expense of synthesis of the skeletal organic matrix resulting in a low calcification rate for this individual.

\subsection{Implications for biomineralisation and ocean acidification}

With the exception of the outlier, corals cultured at high seawater $\mathrm{pCO}_{2}$ had low $\mathrm{pH}_{\mathrm{CF}}$ and $\mathrm{DIC}_{\mathrm{CF}}$. In our dataset the calcification fluid $\mathrm{pH}$ increase is fundamental in concentrating precipitating DIC for calcification (Fig 1b). While it is not clear which DIC species is/are utilised in aragonite precipitation calcification rate is usually strongly dependent on [co-precipitating DIC] $\mathrm{CF}$. This suggests that the decreased calcification rates typically observed in corals cultured at high seawater $\mathrm{pCO}_{2}($ Erez et al., 2011) reflect a reduced ability to concentrate DIC at the calcification site. Corals cultured at high seawater $\mathrm{pCO}_{2}$ may remove more protons from the calcification fluid than their lower seawater $\mathrm{pCO}_{2}$ analogues, partially offsetting the effects of ocean acidification, but they do not usually attain the same high $\mathrm{pH}_{\mathrm{CF}}$ (Venn et al., 2012) and probably do not accumulate DIC $\mathrm{C}_{\mathrm{CF}}$ to the same extent. Corals cultured at low seawater $\mathrm{pH}$ may upregulate genes coding for bicarbonate anion transport (Vidal-Dupiol et al., 2013) but, if this occurred in our samples, it did not compensate for the decrease in calcification fluid DIC.

One coral in our datatset continued to attain high $\mathrm{pH}_{\mathrm{CF}}$ and $\mathrm{DIC}_{\mathrm{CF}}$ at high seawater $\mathrm{pCO}_{2}$ but in this case the coral exhibited a reduced calcification rate suggesting that the coral has a limited energy budget to support proton extrusion from the calcification fluid and meet other calcification demands. We infer that future increases in atmospheric $\mathrm{CO}_{2}$ (and concurrent decreases in seawater $\mathrm{pH}$ ) will likely decrease both coral $\mathrm{pH}_{\mathrm{CF}}$ and $[\mathrm{DIC}]_{\mathrm{CF}}$ and ultimately reduce coral calcification.

\section{Conclusions}

Calcification fluid $\mathrm{pH}$ and [co-precipitating $\mathrm{DIC}$ ] estimates from skeletal $\delta^{11} \mathrm{~B}$ and $\mathrm{B} / \mathrm{Ca}$ are positively correlated in all corals. Corals cultured at high seawater $\mathrm{pCO}_{2}$ usually have relatively low fluid $\mathrm{pH}$ and [precipitating DIC]. [Precipitating DIC] and coral calcification rate are positively correlated in all but one outlier coral and reduced DIC substrate at the calcification site is the likely 
cause of decreased coral calcification rates under ocean acidification scenarios. The outlier coral maintained a high calcification fluid $\mathrm{pH}$ and [co-precipitating $\mathrm{DIC}$ ] at high seawater $\mathrm{pCO}_{2}$ but exhibited a low calcification rate suggesting that corals have a limited energy budget for calcification which is apportioned between proton extrusion from the calcification site and other processes e.g. synthesis of the skeletal organic matrix.

\section{Acknowledgements}

This work was supported by the UK Natural Environment Research Council (award NE/I022973/1) to AAF and NA. NERC Scientific Services provided access to the ion microprobe, and we are indebted to Richard Hinton (EIMF, University of Edinburgh) for his assistance with the analyses. Seawater B/Ca analyses were carried out by Matt Cooper (University of Southampton). We thank Dave Steven, Mark Robertson, Casey Perry, Mike Scaboo and Andy Mackie for their assistance with the culture system build.

\section{References}

Al-Horani, F.A., Al-Moghrabi, S.M., de Beer, D., 2003. The mechanism of calcification and its relation to photosynthesis and respiration in the scleractinian coral Galaxea fascicularis. Mar. Biol. 142, 419-426.

Allen, K.A., Honisch, B., Eggins, S.M., Rosenthal, Y., 2012. Environmental controls on B/Ca in calcite tests of the tropical planktic foraminifer species Globigerinoides ruber and Globigerinoides sacculifer. Earth Planet. Sci. Lett. 351-352, 270-280.

Allison, N., 2017. Reconstructing coral calcification fluid dissolved inorganic carbon chemistry from skeletal boron: an exploration of potential controls on coral aragonite B/Ca. Heliyon, 3 , https://doi.org/10.1016/j.heliyon.2017.e00387.

Allison, N., Cohen, I., Finch, A.A., Erez, J., Tudhope, A.W., 2014. Corals concentrate dissolved inorganic carbon to facilitate calcification. Nat. Commun. 5, 5741, https://doi.org/10.1038/ncomms6741.

Allison, N., Finch, A.A., 2009. Reproducibility of minor and trace element determinations in Porites coral skeletons by secondary ion mass spectrometry, Geochem. Geophys. Geosyst., 10, Q04003, https://doi.org/10.1029/2008GC002239.

Allemand, D., Tambutte, E., Zoccola, D., Tambutte S., 2011. Coral Calcification, Cells to Reefs. In Coral Reefs: An Ecosystem in Transition (eds Z. Dubinksy and N. Stambler). Springer Science, New York. pp. 119-150.

Balan, E., Pietrucci, F., Gervais, C., Blanchard, M., Schott, J., Gaillardet, J., 2016. First-principles study of boron speciation in calcite and aragonite, Geochim. Cosmochim. Acta, 193, https://doi.org/10.1016/j.gca.2016.07.026.

Cai, W.-J., Ma, Y., Hopkinson, B.M., Grottoli, A.G., Warner, M.E., Ding, Q., Hu, X., Yuan, X., Schoepf, V., Xu, H., Han, C., Melman, T.F., Hoadley, KD., Pettay, D.T., Matsui, Y., Baumann, J. H., Levas, S., Ying, Y., Wang, Y. 2016. Microelectrode characterization of coral daytime interior $\mathrm{pH}$ and carbonate chemistry. Nat. Commun. 7, 11144; https://doi.org/10.1038/ncomms11144.

Caldeira, K., Wickett, M.E., 2003. Anthropogenic carbon and ocean pH. Nature 425, 365-365.

Clode, P.L., Marshall, A.T., 2002. Low temperature FESEM of the calcifying interface of a scleractinian coral. Tissue and Cell 34, 187-198.

Cole, C., Finch, A.A., Hintz, C., Hintz, K., Allison, N. 2016. Understanding cold bias: variable response of skeletal $\mathrm{Sr} / \mathrm{Ca}$ to seawater $\mathrm{pCO}_{2}$ in acclimated massive Porites corals, Scientific 
Reports 6, 26888; https://doi.org/10.1038/srep26888.

Cole, C., Finch, A.A., Hintz, C., Hintz, K., Allison, N., 2018. Effects of seawater $\mathrm{pCO}_{2}$ and temperature on calcification and productivity in the coral genus Porites spp.: an exploration of potential interaction mechanisms, Coral Reefs, https://doi.org/10.1007/s00338-018-1672-3.

DeCarlo, T.M., Holcomb, M., McCulloch, M.T., 2018. Reviews and syntheses: Revisiting the boron systematics of aragonite and their application to coral calcification, Biogeosciences, 15, 28192834, https://doi.org/10.5194/bg-15-2819-2018.

Dickson, A.G., 1990. Standard potential of the reaction: $\mathrm{AgCl}(\mathrm{s})+12 \mathrm{H}_{2}(\mathrm{~g})=\mathrm{Ag}(\mathrm{s})+\mathrm{HCl}(\mathrm{aq})$ and the standard acidity constant of the ion $\mathrm{HSO}_{4}{ }^{-}$in synthetic sea water from 273.15 to $318.15 \mathrm{~K}$. J. Chem. Thermodynamics 22,113-127.

Dickson, A.G., Millero, F.J., 1987. A comparison of the equilibrium constants for the dissociation of carbonic acid in seawater media. Deep-Sea Research, 34, 1733-1743.

Elderfield, H., Bertram, C.J., Erez, J., 1996. Biomineralization model for the incorporation of trace elements into foraminiferal calcium carbonate. Earth Planet. Sci. Lett. 142, 409-423.

Erez, J. 1978. Vital effect on the stable-isotope composition seen in foraminifera and coral skeletons. Nature 273, 199-202.

Erez, J., Reynaud, S., Silverman, J., Schneider, K., Allemand, D., 2011. Coral calcification under ocean acidification and global change. In Coral Reefs: An Ecosystem in Transition (eds Z. Dubinksy and N. Stambler). Springer Science, New York. pp. 151-176.

Falini, G., Reggi, M., Fermani, S., Sparla, F., Goffredo, S., Dubinsky, Z., Levi, O., Dauphin, Y., Cuif J.-P., 2013. Control of aragonite deposition in colonial corals by intra-skeletal macromolecules. J. Struct. Biol. 183, 226-238.

Gabitov, R.I., Rollion-Bard, C. Tripati, A., Sadekov, A., 2014. In situ study of boron partitioning between calcite and fluid at different crystal growth rates, Geochimica et Cosmochimica Acta, 137, 81-92 https://doi.org/10.1016/j.gca.2014.04.014.

Gast, J.A., Thompson, T.G., 1959. Evaporation of boric acid from seawater, Tellus, 11, 344-347 https://doi.org/10.1111/j.2153-3490.1959.tb00039.x.

Gebauer, D., Volkel, A., Colfen, H., 2008. Stable prenucleation calcium carbonate clusters, Science, 322, 1819-1822.

Hohn, S., Merico, A., 2012. Modelling coral polyp calcification in relation to ocean acidification. Biogeosciences 9, 4441-4454.

Holcomb, M., DeCarlo, T.M., Gaetani, G.A., McCulloch, M., 2016. Factors affecting B/Ca ratios in synthetic aragonite. Chem. Geol. 437, 67-76.

IPCC Climate Change 2013, 2013. The Physical Science Basis. (eds T.F. Stocker and D.Qin) Cambridge Univ. Press, Cambridge, U.K.

Jury, C.P., Whitehead, R.F., Szmant, A.M., 2010. Effects of variations in carbonate chemistry on the calcification rates of Madracis auretenra (= Madracis mirabilis sensu Wells, 1973): bicarbonate concentrations best predict calcification rates, Global Change Biology, 16, 1632-1644.

Kakihana, K., Kotaka, M., Satoh, S., Nomura, M., Okamoto, M. 1977. Fundamental studies on ion exchange separation of boron isotopes, Bull. Chem. Soc. Japan, 50, 158-163.

Kasemann, S.A., Schmidt, D.N., Bijma, J., Foster, G.L., 2009. In situ boron isotope analysis in marine carbonates and its application for foraminifera and palaeo-pH. Chem. Geol. 260, 138-147.

Klochko, K., Kaufman, A.J., Yao, W.S., Bryne, R.H., Tossell, J. A., 2006. Experimental measurement of boron isotope fractionation in seawater. Earth Planet. Sci. Lett. 248, 276-285. 
Klochko, K., Cody, G., Tossell, J.A., Dera, P., Kaufman, A.J., 2009. Re-evaluating boron speciation in biogenic calcite and aragonite using B-11, Geochim. Cosmochim. Ac, 73, 1890-1900.

Kubota, K., Yokoyama, Y., Ishikawa, T., Obrochta, S., Atsushi, S., 2014. Larger $\mathrm{CO}_{2}$ source at the equatorial Pacific during the last deglaciation. Scientific Reports,

https://doi.org/10.1038/srep05261.

Marubini, F., Barnett, H., Langdon, C., Atkinson, M.J., 2001. Dependence of calcification on light and carbonate ion concentration for the hermatypic coral Porites compressa. Mar. Ecol. Prog. Ser. 220:153-162.

Mass, T., Drake, J.L., Haramaty, L., Kim, J.D., Zelzion, E., Bhattacharya, D., Falkowski, P.G., 2013. Cloning and characterization of four novel coral acid-rich proteins that precipitate carbonates in vitro. Current Biology 23, 1126-1131.

Mavromatis, V., Montouillout, V., Noireaux, J., Gaillardet, J., Schott, J., 2015. Characterization of boron incorporation and speciation in calcite and aragonite from co-precipitation experiments under controlled pH, temperature and precipitation rate. Geochim. Cosmochim. Acta 150, 299-313.

McCulloch, M.T., Falter, J., Trotter, J., Montagna, P., 2012. Coral resilience to ocean acidification and global warming through $\mathrm{pH}$ up-regulation, Nature Climate Change, 2, 623-627.

McCulloch, M.T., D’Olivio, Falter, J. , Holcomb, M., Trotter, J., 2017. Coral calcification in a changing World and the interactive dynamics of $\mathrm{pH}$ and DIC upregulation, Nature Communications, 8, https://doi.org/10.1038/ncomms 15686 .

Mehrbach, C., Culberson, C.H., Hawley, J.E., Pytkowicx, R.M., 1973. ,Measurement of the apparent dissociation constants of carbonic acid in seawater at atmospheric pressure. Limnology and Oceanography, 18, 897-907.

Nir, O., Vengosh, A., Harkness, J.S., Dwye,r G.S., Lahav, O., 2015. Direct measurement of the boron isotope fractionation factor: Reducing the uncertainty in reconstructing ocean paleo-pH, Earth and Planetary Science Letters 414, 1-5.

Noireaux, J., Mavromatis, V., Gaillardet, J., Neuville, D., 2015. Crystallographic control on the boron isotope paleo-pH proxy. Earth Planetary Sci. Lett. 430, 398-407.

Pelejero, C., Calvo, E., McCulloch, M. T., Marshall, J. F., Gagan, M.K., Lough, J.M., Opdyke, B.N., 2005. Preindustrial to modern interdecadal variability in coral reef pH. Science, 309, 2204-2207.

Petit, J.R., Jouzel, J., Raynaud, D., Barkov, N.I., Barnola, J.-M., Basile, I., Bender, M., Chappellaz, J., Davis, M., Delaygue, G., Delmotte, M., Kotlyakov, V.M., Legrand, M., Lipenkov, V.Y., Lorius, C., PÉpin, L., Ritz, C., Saltzman, E., Stievenard, M., 1999. Climate and atmospheric history of the past 420 ky from the Vostok ice core, Antarctica. Nature 399, 429-436.

Rae, J.W.B., Foster, G.L., Schmidt, D.N., Elliott, T., 2011. Boron isotopes and B/Ca ratios in benthic foraminifera: proxies for the deep ocean carbonate system. Earth Planet. Sci. Lett. 302, 404-413 (2011).

Rollion-Bard, C., Blamart, D., Trebosc, J., Tricot, G., Mussi, A., Cuif J.P., 2011. Boron isotopes as pH proxy: a new look at boron speciation in deep-sea corals using 11B MAS NMR and EELS, Geochimica et Cosmochimica Acta 75, 1003-1012

Ross, C.L., Falter, J.L., McCulloch, M.T., 2017. Active modulation of the calcifying fluid carbonate chemistry $(\mathrm{\delta} 11 \mathrm{~B}, \mathrm{~B} / \mathrm{Ca})$ and seasonally invariant coral calcification at sub-tropical limits, Scientific Reports, 7, https://doi.org/10.1038/s41598-017-14066-9.

Schneider, K., Erez, J., 2006. The effect of carbonate chemistry on calcification and photosynthesis in the hermatypic coral Acropora eurystoma. Limnol.. Oceanogr. 51, 1284-1293. 
Sen, S., Stebbins, J.F., Hemming, N.G., Ghosh, B., 1994. Coordination environments of Bimpurities in calcite and aragonite polymorphs - a B-11 mas NMR-study. Am. Mineralogist 79, 819825.

Shinjo, R., Asami, R., Huang, K.-F., You, C.F., Iryu, Y., 2013. Ocean acidification trend in the tropical North Pacific since the mid-20th century reconstructed from a coral archive. Mar. Geol. 342, 58-64.

Tambutte, E., Allemand, D., Mueller, E., Jaubert, J., 1996. A compartmental approach to the mechanism of calcification in hermatypic corals. J. Exp. Biol. 199, 1029-41.

Tambutte, E., Tambutté, S., Segonds, N., Zoccola, D., Venn, A., Erez, J., Allemand D., 2012. Calcein labelling and electrophysiology: insights on coral tissue permeability and calcification. Proc. Royal Soc. B 279, 19-27.

Van de Locht, R., 2014. On the nanostructure of biogenic and bio-inspired calcium carbonate, PhD thesis, University of York, UK.

Venn, A.A., Tambutte, E., Holcomb, M., Allemand, D., Tambutte, S., 2011. Live tissue imaging shows reef corals elevate $\mathrm{pH}$ under their calcifying tissue relative to seawater. PLoS ONE 6, e20013.

Venn, A.A., Tambutte, E., Holcomb, M., Tambutte, S., 2012. Impact of seawater acidification on pH at the tissue-skeleton interface and calcification in reef corals. Proc. Natl. Acad. Sci. 110, 16341639.

Vidal-Dupiol, J., Zoccola, D., Tambutte, E., Grunau, C., Cosseau, C., Smith, K.M., Freitag, M., Dheilly, N.M., Allemand, D., Tambutte, S., 2013. Genes related to ion-transport and energy production are upregulated in response to $\mathrm{CO}_{2}$-driven $\mathrm{pH}$ decrease in corals: new insights from transcriptome analysis. PLoS One 8, e58652; https://doi.org/10.1371/journal.pone.0058652.

Von Euw, S., Zhang, Q., Manichev, V.,Murali, N., Gross, J., Feldman, L.C., Gustafsson, T., Flach, C., Mendelsohn, R., Falkowski, P.G., 2017. Biological control of aragonite formation in stony corals. Science, 356, 933-938. https://doi.org/10.1126/science.aam6371.

Watson, E., 1994. A conceptual model for near-surface kinetic controls on the trace-element and stable isotope composition of abiogenic calcite crystals. Geochim. Cosmochim. Acta 68, 14731488.

Wolthers, M., Nehrke, G., Gustafsson, J.P., Van Cappellen, P., 2012.Calcite growth kinetics: Modelling the effect of solution stoichiometry. Geochim, Cosmochim, Acta 77, 121-134.

Zoccola, D., Ganot, P., Bertucci, A., Caminiti-Segonds, N., Techer, N., Voolstra, C.R., Aranda, M., Tambutté, E., Allemand, D., Casey, J.R., Tambutté, S., 2015. Bicarbonate transporters in corals point towards a key step in the evolution of cnidarian calcification. Sci. Rep. 5, 9983; https://doi.org/10.1038/srep09983.

\section{Author contributions}

$\mathrm{NA}$ and $\mathrm{AAF}$ conceived and designed the experiment, $\mathrm{NA}, \mathrm{AAF}, \mathrm{KH}$ and $\mathrm{CH}$ built the culturing system, NA and CC cultured and analysed the corals, CC and JR analysed the seawater $\delta^{11} B, N A$ analysed the data and wrote the manuscript. All authors read and approved the manuscript.

\section{Competing Financial Interests}

The authors declare no competing financial interests. 
Table 1. Physical and chemical characteristics of the seawater and coral skeletons in each treatment, measured over the 5-week experimental period. Seawater values are mean \pm standard deviation $(1 \sigma)$ of $n$ measurements. Dissolved inorganic carbon (DIC) and total alkalinity measurements were used to calculate seawater $\mathrm{pH}$ (total) using $\mathrm{CO}_{2}$ sys and equilibrium constants for carbonic acid (Mehrbach et al., 1973), refit by Dickson and Millero (1987) and $\mathrm{HSO}_{4}$ (Dickson, 1990). Skeletal $\delta^{11} \mathrm{~B}$ and $\mathrm{B} / \mathrm{Ca}$ are means $\pm 95 \%$ confidence limits. Calcification rates $\left(\mu \mathrm{mol} \mathrm{CaCO}_{3}\right.$ $\mathrm{cm}^{-2}$ day $^{-1}$ ) are means \pm standard deviations. Duplicates of the $P$. murrayensis genotype were cultured at 417 and $750 \mu$ atm and the values measured for each colony are shown separately.

\begin{tabular}{|c|c|c|c|c|}
\hline & & \multicolumn{3}{|c|}{ Seawater $\mathrm{pCO}_{2}$} \\
\hline & & $180 \mu \mathrm{atm}$ & $400 \mu$ atm & $750 \mu$ atm \\
\hline \multicolumn{5}{|c|}{ Seawater characteristics } \\
\hline \multicolumn{2}{|c|}{ Temperature $\left({ }^{\circ} \mathrm{C}\right)$} & $25.3 \pm 0.1$ & $25.2 \pm 0.2$ & $25.1 \pm 0.2$ \\
\hline \multicolumn{2}{|l|}{ Salinity } & $35.1 \pm 0.04$ & $35.2 \pm 0.08$ & $35.2 \pm 0.05$ \\
\hline \multicolumn{2}{|c|}{ Total alkalinity $\left(\mu \mathrm{mol} \mathrm{kg}{ }^{-1}\right)$} & $2289 \pm 14 \quad(n=16)$ & $2290 \pm 8(n=16)$ & $2293 \pm 5(n=16)$ \\
\hline \multicolumn{2}{|c|}{ Total DIC $\left(\mu \mathrm{mol} \mathrm{kg}^{-1}\right)$} & $1831 \pm 11(n=5)$ & $1999 \pm 8(n=5)$ & $2113 \pm 11(n=5)$ \\
\hline \multicolumn{2}{|c|}{ Seawater pH (total scale) } & 8.28 & 8.03 & 7.81 \\
\hline \multicolumn{2}{|c|}{ Seawater $[\mathrm{B}]\left(\mu \mathrm{mol} \mathrm{kg}{ }^{-1}\right)$} & $392 \pm 8(n=5)$ & $395 \pm 6(n=5)$ & $405 \pm 8(n=5)$ \\
\hline \multicolumn{2}{|c|}{ Seawater [Ca] $\left(\mathrm{mmol} \mathrm{kg}^{-1}\right)$} & $9.78 \pm 0.08(n=5)$ & $9.84 \pm 0.10(n=5)$ & $9.86 \pm 0.07(n=5)$ \\
\hline \multicolumn{2}{|c|}{ Seawater $\delta^{11} \mathrm{~B}(\%)$} & $-1.07 \pm 0.20(n=4)$ & $-0.90 \pm 0.11(n=3)$ & $-1.00 \pm 0.15(n=3)$ \\
\hline \multicolumn{5}{|c|}{ Skeleton characteristics } \\
\hline & P. lutea 1 & $20.8 \pm 0.6(n=3)$ & $18.9 \pm 1.0(n=4)$ & $17.8 \pm 2.6(n=4)$ \\
\hline \multirow{3}{*}{$\begin{array}{l}\text { Calcification } \\
\text { rate }\end{array}$} & P. lutea 2 & $21.3 \pm 2.9(n=3)$ & $9.86 \pm 2.0(n=2)$ & $4.22 \pm 1.2(n=3)$ \\
\hline & P. murrayensis & $22.8 \pm 0.8(n=3)$ & $16.7 \pm 0.8(n=2)$ & $9.30 \pm 4.3(n=3)$ \\
\hline & & & $15.0 \pm 1.1(n=3)$ & $11.0 \pm 1.5(n=3)$ \\
\hline \multirow{4}{*}{$\delta^{11} \mathrm{~B}$} & P. lutea 1 & $-16.0 \pm 0.6(n=17)$ & $-17.5 \pm 0.5(n=21)$ & $-17.0 \pm 0.4(n=22)$ \\
\hline & P. lutea 2 & $-15.0 \pm 0.8(n=21)$ & $-17.0 \pm 0.7(n=21)$ & $-18.0 \pm 0.7(n=20)$ \\
\hline & P. murrayensis & $-14.6 \pm 0.7(n=24)$ & $-16.5 \pm 0.7(n=18)$ & $-15.8 \pm 0.5(n=19)$ \\
\hline & & & $-17.5 \pm 0.4(n=21)$ & $-18.1 \pm 0.5(n=19)$ \\
\hline \multirow{4}{*}{$\mathrm{B} / \mathrm{Ca}$} & P. lutea 1 & $0.367 \pm 0.011(n=17)$ & $0.340 \pm 0.018(n=2))$ & $0.398 \pm 0.019(n=22)$ \\
\hline & P. lutea 2 & $0.360 \pm 0.016(n=21)$ & $0.367 \pm 0.008(n=21)$ & $0.381 \pm 0.009(n=20)$ \\
\hline & P. murrayensis & $0.343 \pm 0.016(n=24)$ & $0.329 \pm 0.011(n=18)$ & $0.316 \pm 0.014(n=19)$ \\
\hline & & & $0.306 \pm 0.014(n=21)$ & $0.317 \pm 0.015(n=19)$ \\
\hline $\mathrm{pH}_{\mathrm{CF}}$ & P. lutea 1 & $8.50 \pm 0.04(n=17)$ & $8.39 \pm 0.03(n=2))$ & $8.42 \pm 0.02(n=22)$ \\
\hline \multirow[t]{3}{*}{ Total scale } & P. lutea 2 & $8.56 \pm 0.05(n=21)$ & $8.43 \pm 0.04(n=21)$ & $8.36 \pm 0.05(n=20)$ \\
\hline & P. murrayensis & $8.58 \pm 0.04(n=24)$ & $8.46 \pm 0.04(n=18)$ & $8.51 \pm 0.03(n=19)$ \\
\hline & & & $8.39 \pm 0.03(n=21)$ & $8.35 \pm 0.04(n=19)$ \\
\hline
\end{tabular}


Table 2. . Summary of significant differences ( $p=\leq 0.05$ one way ANOVA followed by Tukey's pairwise comparisons) in $\mathrm{pH}_{\mathrm{CF}}$ (estimated from skeletal $\delta^{11} \mathrm{~B}$ ) between individuals of the same coral genotype in different seawater $\mathrm{pCO}_{2}$ treatments $(180,400$ or $750 \mu \mathrm{atm})$. Data from duplicate corals are combined for this analysis.

\begin{tabular}{|l|c|}
\hline & $\mathrm{pH}_{\mathrm{CF}}$ \\
\hline Genotype 1 & $180>400$ \\
(P. lutea) & $180>750$ \\
& $400=750$ \\
\hline Genotype 2 & $180>400$ \\
(P. lutea) & $180>750$ \\
& $400=750$ \\
\hline Genotype 3 & $180>400$ \\
(P. murrayensis) & $180>750$ \\
& $400=750$ \\
\hline
\end{tabular}


Figure 1. a) Coral $\mathrm{pH}_{\mathrm{CF}}$ (estimated from skeletal $\delta^{11} \mathrm{~B}$ ), and b) relationship between $\mathrm{pH}_{\mathrm{CF}}$ and $\left[\mathrm{CO}_{3}{ }^{2-}\right]_{\mathrm{CF}}$, assuming $\mathrm{CO}_{3}{ }^{2-}$ only is utilized in calcification and $\left[\mathrm{HCO}_{3}{ }^{-}+\mathrm{CO}_{3}{ }^{2-}\right]_{\mathrm{CF}}$, assuming both $\mathrm{HCO}_{3}$ - and $\mathrm{CO}_{3}{ }^{2-}$ are utilized in calcification (both $\mu \mathrm{mol} \mathrm{kg}{ }^{-1}$ ). $\left[\mathrm{HCO}_{3}^{-}\right]_{\mathrm{CF}}$, assuming $\mathrm{HCO}_{3}$ - only is utilized in calcification, is not shown but exhibits the same distribution with $\left[\mathrm{HCO}_{3}{ }^{-}\right]_{\mathrm{CF}}$ spanning $\left.2472-3659 \mu \mathrm{mol} \mathrm{kg}{ }^{-1}\right)$. Symbols denote coral genotypes and colours denote seawater $\mathrm{pCO}_{2}$ treatment. pHCF error bars are calculated from $95 \%$ confidence limits of skeletal $\delta 11 \mathrm{~B}$ analyses while $\left[\mathrm{CO}_{3}{ }^{2-}\right]_{\mathrm{CF}}$, and $\left[\mathrm{HCO}_{3}{ }^{-}+\mathrm{CO}_{3}{ }^{2-}\right]_{\mathrm{CF}}$ error bars are calculated from propagating $95 \%$ confidence limits in $\mathrm{B} / \mathrm{Ca}$ and $\mathrm{\delta} 11 \mathrm{~B}$ analyses onto DIC system estimates.

$$
\begin{aligned}
& \square 180 \mu \mathrm{atm} \\
& \square 400 \mu \mathrm{atm} \\
& \square 750 \mu \mathrm{atm}
\end{aligned}
$$

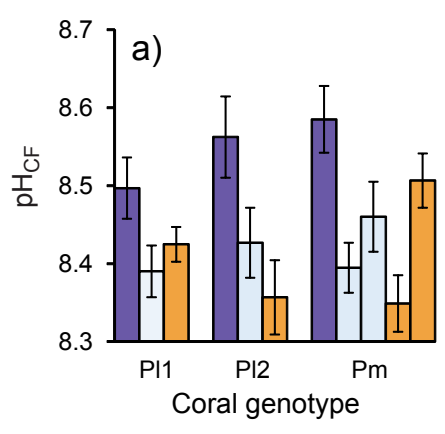

- P. lutea 1

․ P. lutea 2

$\triangle$ P. murrayensis

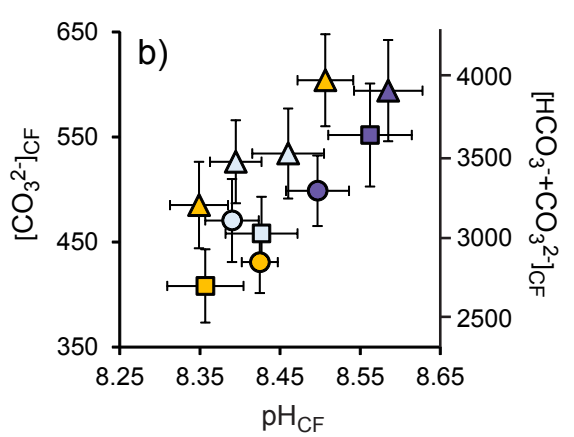

Figure 2. Correlations between pHCF and $\left[\mathrm{CO}_{3}{ }^{2-}\right]_{\mathrm{CF}}$ and $\left[\mathrm{HCO}_{3}{ }^{-}+\mathrm{CO}_{3}{ }^{2-}\right]_{\mathrm{CF}}\left(\right.$ both $\left.\mu \mathrm{mol} \mathrm{kg}^{-1}\right)$ for all corals by species. For explanation of error bars see Figure 1. Coefficients of determination ( $\left.r^{2}\right)$ for P. lutea and P. murrayensis are 0.84 and 0.83 respectively.

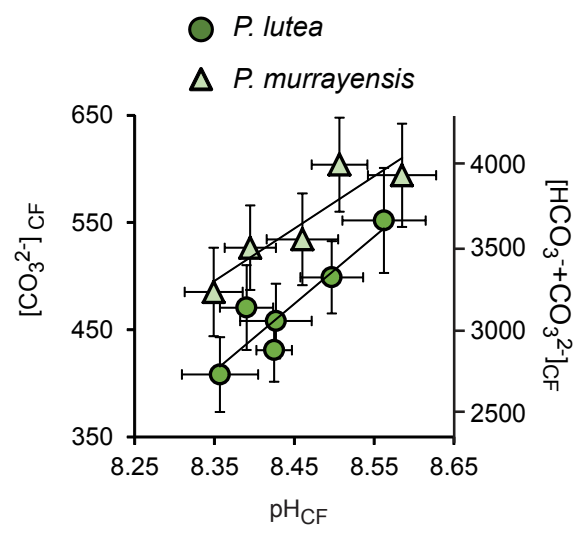


Figure 3. Predicted $\left[\mathrm{CO}_{3}{ }^{2-}\right]_{\mathrm{CF}},\left[\mathrm{HCO}_{3}{ }^{-}\right]_{\mathrm{CF}}$ and $\left[\mathrm{HCO}_{3}{ }^{-}+\mathrm{CO}_{3}{ }^{2-}\right]_{\mathrm{CF}}$, assuming the calcification fluid operates as: a-c) an open system in equilibrium with overlying $\mathrm{CO}_{2}$ of 180,400 or $750 \mu$ atm or d-f) an open system where $\mathrm{CO}_{2}$ diffusion into the fluid is controlled by $\Delta \mathrm{C}_{\mathrm{w}}$. Observed coral data are overlain onto each graph. Symbols denote coral genotypes and colours denote seawater $\mathrm{pCO}_{2}$ treatment.
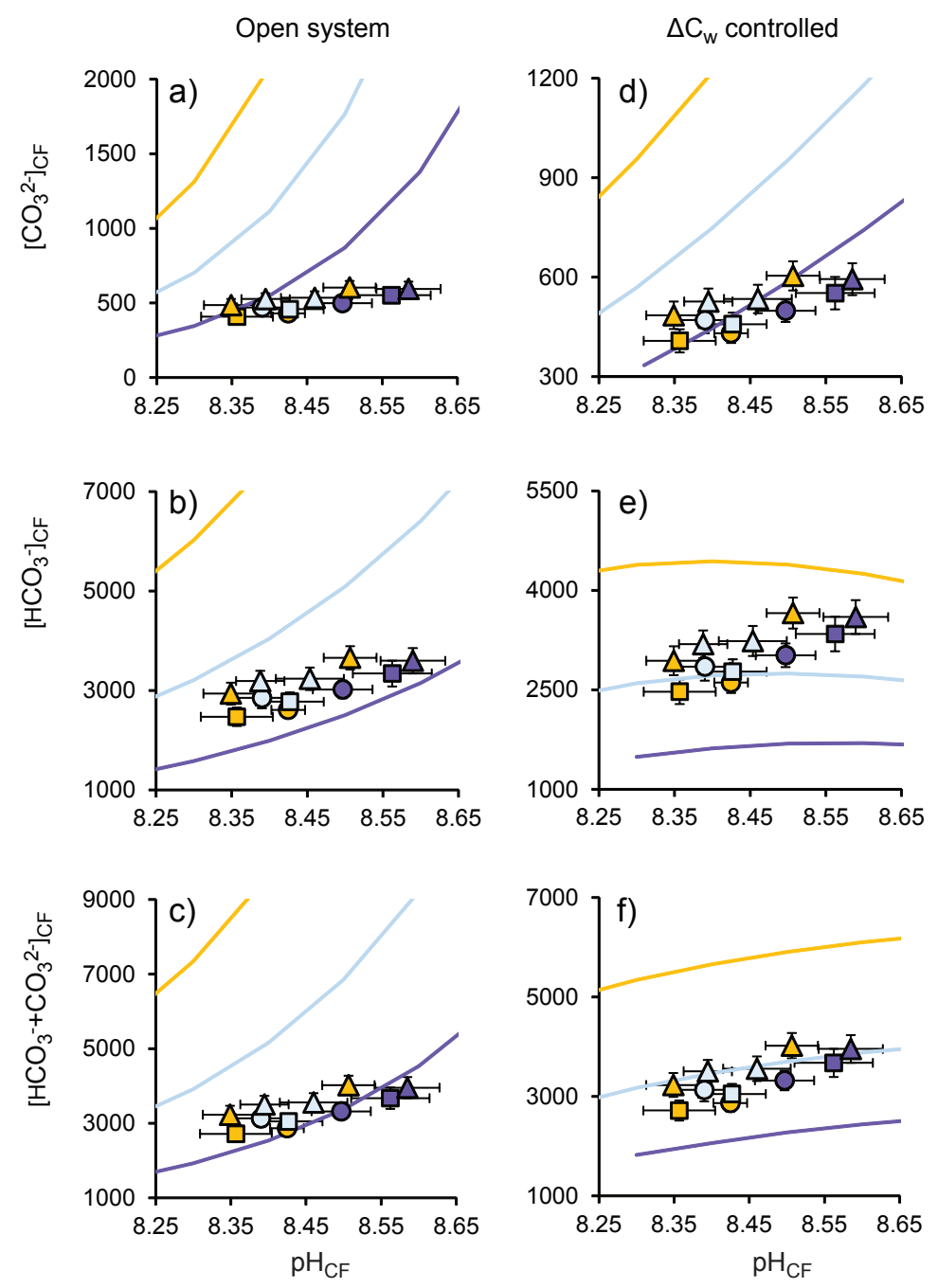
Figure 4. Estimated $\left[\mathrm{CO}_{2}\right]\left(\mu \mathrm{mol} \mathrm{kg}{ }^{-1}\right)$ of a fluid with total [DIC] as in Table 1. Black horizontal lines indicate the $\left[\mathrm{CO}_{2}\right]$ of an overlying ambient seawater at a) $180 \mu \mathrm{atm}$, b) $400 \mu \mathrm{atm}$ and c) $750 \mu$ atm. These lines are extended across the entire $\mathrm{pH}_{\mathrm{CF}}$ range to ease visualisation of $\Delta \mathrm{C}_{\mathrm{W}}$ although the $\mathrm{pH}$ of the overlying seawater is constant. $\Delta \mathrm{C}_{\mathrm{W}}$ indicates the $\mathrm{CO}_{2}$ concentration gradient between the calcification fluid and ambient seawater at $\mathrm{pH} 8.5$ which facilitates $\mathrm{CO}_{2}$ diffusion from seawater into the fluid.
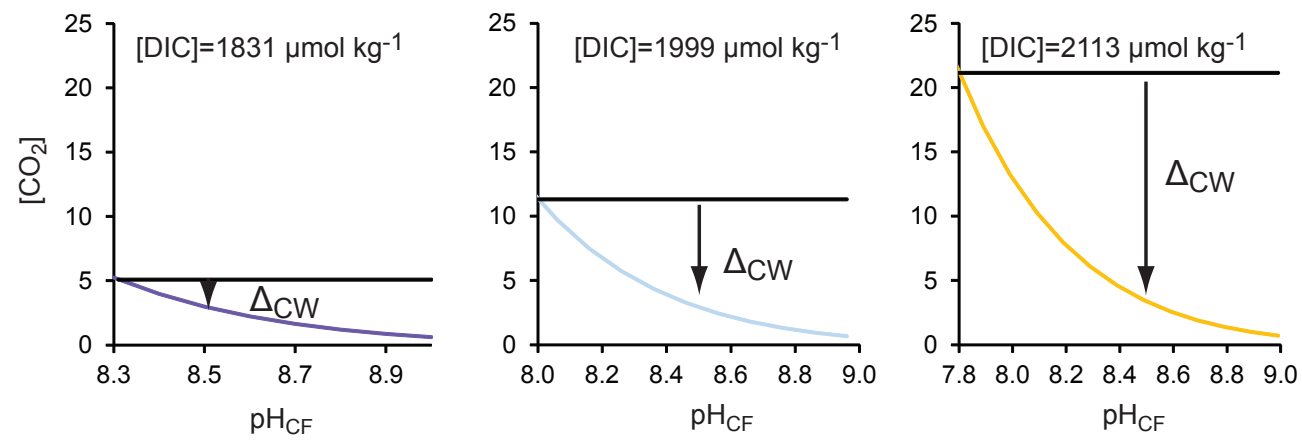

Figure 5. Correlations between coral calcification rate $\left(\mu \mathrm{mol} \mathrm{CaCO}_{3} \mathrm{~cm}^{-2}\right.$ day-1) and a) $\left[\mathrm{CO}_{3}{ }^{2-}\right]_{\mathrm{CF}}$ and $\left[\mathrm{HCO}_{3}{ }^{-}+\mathrm{CO}_{3}{ }^{2-}\right]_{\mathrm{CF}}$ and $\left.\mathrm{b}\right)\left[\mathrm{H}^{+}\right] \mathrm{sw}-\left[\mathrm{H}^{+}\right]_{\mathrm{CF}}$ for each coral genotype. Coefficients of determination $\left(\mathrm{r}^{2}\right)$ for $\mathrm{P}$. lutea 1, P. lutea 2 and P. murrayensis are a) $0.94,1.00$ and 1.00 (excluding the outlier P. murrayensis data point) and b) $0.88,0.88$ and 0.90 (including all data points) respectively. $\left[\mathrm{CO}_{3}{ }^{2-}\right]_{\mathrm{CF}}$ and $\left[\mathrm{HCO}_{3}{ }^{-}+\mathrm{CO}_{3}{ }^{2-}\right]_{\mathrm{CF}}$ error bars are calculated from propagating $95 \%$ confidence limits in $\mathrm{B} / \mathrm{Ca}$ and $\delta^{11} \mathrm{~B}$ analyses onto DIC system estimates. Calcification rate error bars indicate the standard deviation of multiple $(n=3-4)$ estimates over the 5 week experimental period.

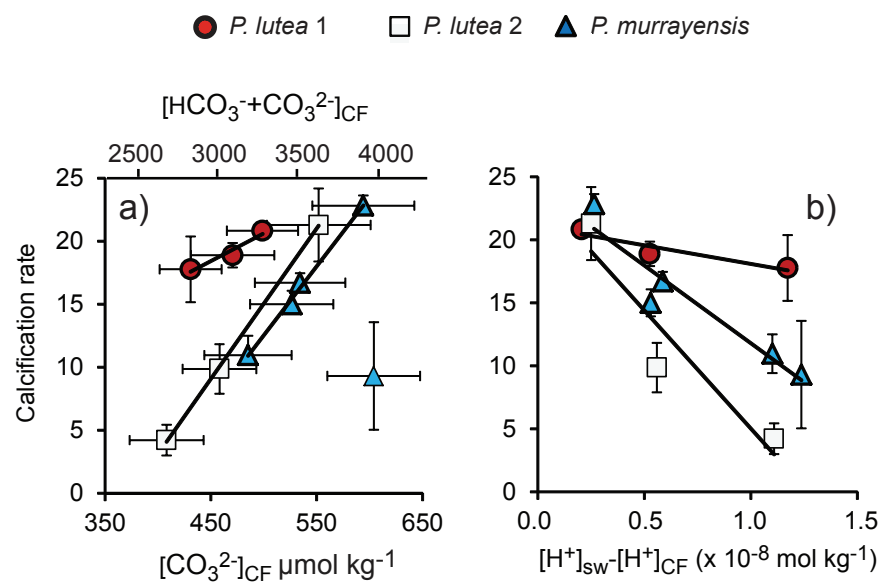

